\title{
Exploring How to Use Groundwater Chemistry to Identify Migration of Methane near Shale Gas Wells in the Appalachian Basin
}

\author{
Tao Wen, ${ }^{*} \dagger$ Josh Woda, ${ }^{\ddagger}$ Virginia Marcon,,${ }^{\ddagger}$ Xianzeng Niu,,${ }^{\dagger}$ Zhenhui Li,${ }^{\S}$ and Susan L. Brantley ${ }^{\dagger,}$ \\ †Earth and Environmental Systems Institute, Pennsylvania State University, University Park, \\ Pennsylvania 16802, United States \\ Department of Geosciences, Pennsylvania State University, University Park, Pennsylvania 16802, \\ United States \\ ${ }^{\S}$ College of Information Sciences and Technology, Pennsylvania State University, University Park, \\ Pennsylvania 16802, United States
}

"Corresponding author: Earth and Environmental Systems Institute, Pennsylvania State University, University Park, PA 16802, United States

Phone: 734-730-8814; E-mail: tzw138@ @su.edu

SI file includes two SI Text, four SI Figures, and five SI Tables 


\section{Text S1 Descriptions of Equilibrium and Reactive Transport Model}

\section{Simulations}

\section{Geochemical Modeling of Redox Equilibration}

In groundwater sampled in one homeowner well (HO4) and other sites in the valley of Sugar Run, an increase in methane concentration was observed and followed by an increase and then decrease in iron concentration ${ }^{1}$. The decrease in iron was roughly followed by a decline in sulfate concentrations. Woda et al. (2018) ${ }^{1}$ hypothesized that methane that entered the aquifer was first oxidized by oxygen until the aquifer became anaerobic. After that, Woda et al. ${ }^{1}$ argued that methane was used as an electron donor by dissimilatory iron reducing microorganisms, and then subsequently by sulfate reducing microorganisms. Such anaerobic oxidation of methane (AOM) coupled to iron-oxide or sulfate reduction has been hypothesized for groundwaters in many systems to follow reactions such as shown below ${ }^{2,3}$ :

$$
\begin{aligned}
& \mathrm{CH}_{4}+8 \mathrm{Fe}(\mathrm{OH})_{3}+15 \mathrm{H}^{+} \rightarrow \mathrm{HCO}^{-}+8 \mathrm{Fe}^{2+}+21 \mathrm{H}_{2} \mathrm{O} \\
& \mathrm{CH}_{4}+\mathrm{SO}_{4}^{2-} \rightarrow \mathrm{HCO3}^{-}+\mathrm{HS}^{-}+\mathrm{H}_{2} \mathrm{O}
\end{aligned}
$$

At Sugar Run, Woda et al. ${ }^{1}$ hypothesized that the increase in dissolved iron was caused by reduction of $\mathrm{Fe}(\mathrm{III})$-oxide particles or coatings in the aquifer to produce aqueous ferrous iron and the decrease in sulfate was caused by reduction to sulfide species.

These ideas about evolution of water chemistry during a methane invasion are explored here in two types of simple model. The first model was run as a series of equilibrium calculations at $25^{\circ} \mathrm{C}$ (with Geochemist's Workbench version 9.0 and thermo.dat). This model was used to explore the boundary conditions for the open system under ambient conditions where thermodynamic data are best known. The second model was a kinetic simulation using CrunchFlow ${ }^{4}$. This model of a well-mixed batch-reactor was developed to explore the evolution 
of groundwater after the invasion of methane in the presence of iron-oxides and iron- and sulfatereducing bacteria (FeRB and $\mathrm{SRB}$, respectively). This somewhat more realistic reactive transport model was run at temperature of $25^{\circ} \mathrm{C}$. Nonetheless, neither the equilibrium nor the reactive transport model was run in open-system mode. Therefore, in each case separate batch calculations were made with different initial sulfate concentrations to explore the effect of influxes of sulfate as groundwater flows through the natural system.

\section{Equilibrium Batch Model}

We simulated the impact of anomalous methane on groundwater using chemistry averaged for all samples from the large groundwater dataset (Table S1a) that contain high methane ( $\geq$ $10 \mathrm{mg} / \mathrm{L})$, elevated sulfate $(\geq 6 \mathrm{mg} / \mathrm{L})$, and elevated iron $(\geq 0.3 \mathrm{mg} / \mathrm{L})$ concentrations. For example, the average $\mathrm{pH}$ of these waters was 8.0 and $\left[\mathrm{Na}^{+}\right]$was $274 \mathrm{mg} / \mathrm{L}$. Equilibrium was calculated for a composition in the presence of goethite and then the partial pressure of methane was increased in the simulation from $1 \times 10^{-6}$ to 1 atm (Figure S2). Simulations with hematite instead of goethite (not shown) differed by less than 5\%. Given that the reduction of iron usually occurs before sulfate reduction in aquifers, the sulfur redox pair $\left(\mathrm{HS}^{-} / \mathrm{SO}_{4}\right)$ was not allowed to equilibrate until methane concentrations reached $\sim 8 \mathrm{mg} / \mathrm{L}$. Supersaturated minerals were allowed to precipitate.

Figure S2 shows calculated concentrations of dissolved ferrous iron, sulfate, methane, and hydrogen sulfide versus $\mathrm{pCH}_{4}$. The current atmospheric concentration of methane, $1.9 \times 10^{-6}$ (by volume), equilibrates at $25^{\circ} \mathrm{C}$ to yield an aqueous concentration of $0.08 \mu \mathrm{g} / \mathrm{L} .{ }^{5}$ Therefore, all waters above $8 \times 10^{-5} \mathrm{mg} / \mathrm{L} \mathrm{CH}_{4}$ at ambient temperature are supersaturated with respect to methane in the atmosphere today; the waters could, however, be in equilibrium with higher $\mathrm{pCH}_{4}$ within an aquifer. For example, bubbling of groundwaters in springs at the surface signifies $\mathrm{pCH}_{4}=1 \mathrm{~atm}$. 
As shown in Figure $\mathrm{S} 2$, at $\mathrm{pCH}_{4}=1$ atm and $25^{\circ} \mathrm{C}$, the aqueous concentration equals $26 \mathrm{mg} / \mathrm{L}$. Concentrations reported in the literature that are $>26 \mathrm{mg} / \mathrm{L}$ likely reflect waters that equilibrated at greater depths where $\mathrm{pCH}_{4}>1$ atm or anomalies related to sampling and analysis.

As shown in Figure S2, values of $\left[\mathrm{Fe}^{2+}\right]$ were observed to equal $\sim 0.3 \mathrm{mg} / \mathrm{L}$ at $\mathrm{pCH}_{4}=10^{-4}$ $\operatorname{atm}\left(0.005 \mathrm{CH}_{4} \mathrm{mg} / \mathrm{L}\right)$ and $\left[\mathrm{Fe}^{2+}\right]$ increased to values as high as $10 \mathrm{mg} / \mathrm{L}$ during equilibration with methane, as long as $\mathrm{SO}_{4}$ was not reduced to sulfide. This is roughly consistent with the highest iron concentrations reported in homeowner wells $(3 \mathrm{mg} / \mathrm{L})$ or in groundwater seeps $(17 \mathrm{mg} / \mathrm{L})$ in Sugar Run valley where methane leakage is thought to be ongoing over 8 years. ${ }^{1}$ Conceptually, these results can be understood if we simply write the reaction describing equilibrium between goethite and $\mathrm{CH}_{4}$ in water (this is a simplified version of the reaction catalyzed by bacteria):

$$
\text { Goethite }+2 \mathrm{H}^{+}+0.125 \mathrm{CH}_{4(\mathrm{~g})}=1.75 \mathrm{H}_{2} \mathrm{O}+\mathrm{Fe}^{2+}+0.125 \mathrm{CO}_{2(\mathrm{~g})}
$$

The equation describing this equilibrium can be written as:

$$
10.65=2 \mathrm{pH}+\log \left[\mathrm{Fe}^{2+}\right]+0.125 \times \log \mathrm{pCO}_{2}-0.125 \times \log \mathrm{pCH}_{4}
$$

Here, for simplicity, we have assumed $25^{\circ} \mathrm{C}$ and activity and fugacity coefficients set to unity. As the $\mathrm{pCO}_{2} / \mathrm{pCH}_{4}$ changes with addition of $\mathrm{CH}_{4}$ to the system, eventually siderite is expected to precipitate. When siderite and goethite are both present at equilibrium with $\mathrm{pCH}_{4}=1 \mathrm{~atm}$, the $\left[\mathrm{Fe}^{2+}\right]$ can be calculated from:

$$
\log \left[\mathrm{Fe}^{2+}\right]=(9.826-1.75 \mathrm{pH}) / 0.875
$$

This equation shows that $\left[\mathrm{Fe}^{2+}\right]$ equals about $10 \mathrm{mg} / \mathrm{L}$ at $\mathrm{pH} 7.5$ and that the maximum in ferrous iron concentration is a strong function of $\mathrm{pH}$.

Recognizing that goethite may become depleted or armored and thus might no longer be available as an electron acceptor, sulfate was allowed to equilibrate with sulfide once $\left[\mathrm{Fe}^{2+}\right]=8$ $\mathrm{mg} / \mathrm{L}$ (Figure S2). As the sulfide concentration increased by equilibration with $\mathrm{CH}_{4}$, pyrite 
precipitates, depressing concentration of $\mathrm{Fe}^{2+}$. In the natural system, the extent of drop in $\mathrm{Fe}^{2+}$ would be controlled to some extent by how much sulfur is brought into the system in the water, but in this model we did not allow open-system influxes of reactants. In effect, we ran batch simulations with different initial S contents to explore open-system effects. If the initial water contains a relatively high sulfate concentration in these calculated equilibria, the initial increase in dissolved ferrous iron concentration is followed by a decrease as sulfate is replaced by $\mathrm{HS}^{-}$at equilibrium. In contrast, in groundwater containing very low concentrations of sulfate (modeling results not shown), hydrogen sulfide concentrations increase with methane concentration without reaching pyrite saturation and iron concentrations can remain elevated.

We interpret these models to indicate that early in the evolution of a low-sulfate aquifer, a decrease in dissolved oxygen and an increase in $\left[\mathrm{Fe}^{2+}\right]$ are expected to accompany an influx of methane. However, the ferric iron minerals in the aquifer slowly become depleted and/or the ferric mineral surface becomes armored by sorbed ferrous iron. As more sulfate enters the open-system aquifer along with the influx of methane, Fe can no longer function as the electron acceptor. Eventually, sulfate becomes the predominant electron acceptor, and values of $\left[\mathrm{SO}_{4}{ }^{2-}\right]$ and $\left[\mathrm{Fe}^{2+}\right]$ decrease while iron sulfides precipitate.

\section{Well-mixed CrunchFlow Batch Model}

In the CrunchFlow model, a volume of groundwater $(100 \mathrm{~mL})$ was reacted with $0.001 \%$ ( $\mathrm{vol} / \mathrm{vol}$ ) goethite and $1 \%$ quartz. The initial groundwater chemistry was set equal to that observed at presumably contaminated homeowner well HO4 in Sugar Run ${ }^{1}$ and was mixed with sufficient methane to attain a concentration of $160 \mathrm{mg} / \mathrm{L}\left(0.01 \mathrm{~mol} \mathrm{~L}^{-1}\right)$. Methane was set at such a high level to ensure it was not consumed during simulation. Table S1b lists initial aqueous chemistry and primary species. Two models were run for different initial sulfate concentrations: one with 0.0002 
mol L ${ }^{-1}$ (i.e., the measured sulfate concentration in baseline sample from HO4 at Sugar Run ${ }^{1}$ ) and the other with $0.002 \mathrm{~mol} \mathrm{~L}^{-1}$ (i.e., 10xbaseline value at site HO4). This allowed exploration of the effects of different initial sulfate concentrations on the evolution of groundwater chemistry at impacted sites and was used as a limited modelling approach to simulate a more open system. The mixture was allowed to react toward equilibrium for 1000 days at $25^{\circ} \mathrm{C}$. The secondary aqueous species defined in the model are $\mathrm{OH}^{-}, \mathrm{CO}_{3}{ }^{2-}, \mathrm{HCO}_{3}{ }^{-}, \mathrm{S}^{2-}, \mathrm{HS}^{-}$, and $\mathrm{NH}_{4}^{+}$. Modeling results are shown in Figure S3.

The modeled reaction network is defined by both mineral and microbially-mediated kinetic reactions. The rates of each microbially-mediated reaction included in the model are defined by a Monod-type rate $\operatorname{law}^{6}$ as shown in Equation (S6):

$R_{m}=\mu_{\max } C_{C_{5} H_{7} O_{2} N} \frac{[D]}{[D]+K_{\text {half }, E D}} \times \frac{[A]}{[A]+K_{\text {half }, E A}} \times \frac{K_{I, H}}{[I]+K_{I, H}}$

Here, $R_{m}$ is the rate of substrate metabolism $\left(\mathrm{mol} \mathrm{kg}^{-1} \mathrm{yr}^{-1}\right) ; \mu_{\max }$ is the maximum specific growth rate of cells of composition $C_{C_{5} H_{7} O_{2} N}\left(\mathrm{~mol} \mathrm{~s}^{-1}\right.$ microbe cell $\left.{ }^{-1}\right) ;\left[C_{C_{5} H_{7} O_{2} N}\right]$ is the concentration of microbial cell biomass (mol-biomass $\mathrm{kg}^{-1}$ ); $[D]$ is the concentration of electron donor, $[A]$ is the concentration of the electron acceptor, and $[I]$ is the concentration of any inhibiting species (mol $\left.\mathrm{kg}^{-1}\right) ; K_{\text {half, }}$ is the half saturation constant for the electron donor (ED) and electron acceptor (EA) $(\mathrm{mol} \mathrm{L}-1) ; \mathrm{K}_{I, H}$ is the inhibition coefficient for the inhibiting species.

The inhibition treatment is included because without it, $\mathrm{SO}_{4}$ reduction and $\mathrm{Fe}(\mathrm{III})$-reduction occur simultaneously in the model; in nature, in contrast, Fe is usually reduced first ${ }^{7}$. Specifically, in microbially-mediated reactions in the natural environment, multiple electron acceptors such as oxygen, nitrate, manganese, iron-oxides, and sulfate often co-exist in disequilibrium. These electron acceptors are utilized by multiple functioning microbial groups, generally in the order of the biogeochemical redox ladder ${ }^{8}$. Although it is still debated as to whether this redox ladder is 
dictated by thermodynamics or kinetics ${ }^{9}$, typically it is assumed that each redox reaction will release different amounts of energy per mole of electron and thus each is utilized in sequence. This is simulated in the CrunchFlow model through use of the inhibiting term in Equation (S6). With the inhibition term, sulfate reduction only occurs at significant rates when Fe(III) oxide concentrations are low compared to the inhibition constant.

As energy is released per mole of electrons from the electron donor in the modelled system, microbial biomass $\left(\mathrm{C}_{5} \mathrm{H}_{7} \mathrm{O}_{2} \mathrm{~N}\right)$ grows or is maintained. The fraction of the energy released from the redox reaction that is allocated to the synthesis of cells $\left(f_{s}\right.$; anabolic pathway) versus the fraction of energy allocated to energy production only ( $f_{e}$; catabolic pathway) can be defined for each reaction ${ }^{6}$. The value of $f_{s}$ decreases from the high energy yield associated with aerobic oxidation down the redox ladder to less energy-producing reactions. The sum of the two fractions must equal unity. To implement the treatment, we can consider half reactions instead of treating the whole reactions as in Equations $\mathrm{S} 1$ and $\mathrm{S} 2: R_{a}$ is the electron acceptor half reaction, $R_{d}$ is the electron donor half reaction, and $R_{c}$ is the cell synthesis half reaction. By definition, the energy production reaction (catabolic pathway), $R_{e}$, for microbes must satisfy $R_{e}=R_{a}-R_{d}$ and that of the cell synthesis reaction (anabolic pathway), $R_{s}$ must satisfy $R_{s}=R_{c}-R_{d}$. To treat both catabolism and anabolism, we define values of $f_{e}$ and $f_{s}$ as the fractions of energy produced by the overall electron transfer, $R$, that describes the catabolic energy consumption reaction and anabolic cell synthesis reaction, respectively. We combine the two pathways as:

$$
R=f_{e} \cdot\left(R_{a}-R_{d}\right)+f_{s} \cdot\left(R_{c}-R_{d}\right)=f_{e} \cdot R_{a}+f_{s} \cdot R_{c}-R_{d}
$$

For electron acceptors higher on the redox ladder, more energy can be apportioned into cell synthesis than cell maintenance ( $f_{s}$ is larger). For example, the Gibbs free energy of reaction of AOM coupled to sulfate reduction in incubation experiments releases to organisms $14 \mathrm{~kJ}$ per mole 
of methane reacted; in contrast, AOM coupled to iron-reduction, a species higher in the biogeochemical redox ladder, provides organisms with $270.3 \mathrm{~kJ}$ per mole of methane reacted ${ }^{2}$. In turn, although the fraction of energy attributed to cell production $\left(f_{s}\right)$ is not a well known quantity, in the model it is set higher for AOM coupled to iron-reduction than for sulfate reduction $(0.4$ and 0.08, respectively). Therefore, for AOM coupled to iron reduction, $f_{e}$ was set to $0.6\left(=1-f_{s}\right)$ and for AOM coupled to sulfate reduction $f_{e}$ was set to 0.92 following Li et al. (2010) ${ }^{7}$.

The equations used in the model are listed below for AOM coupled to iron reduction (Equations S8-S11) and AOM coupled to sulfate reduction (Equations S12-S15).

$\underline{\text { AOM coupled to iron reduction }}\left(f_{e}=0.60, f_{s}=0.40\right)$

$\mathrm{R} \mathrm{d}: \frac{1}{8} \mathrm{CH}_{4}+\frac{3}{8} \mathrm{H}_{2} \mathrm{O} \rightarrow \frac{1}{8} \mathrm{HCO}_{3}+\frac{9}{8} H^{+}+e^{-}$

$\mathrm{R}_{\mathrm{a}}: \mathrm{FeOOH}(s)+3 \mathrm{H}^{+}+e^{-} \rightarrow \mathrm{Fe}^{2+}+2 \mathrm{H}_{2} \mathrm{O}$

$\mathrm{R}_{\mathrm{c}}: \frac{1}{4} \mathrm{HCO}_{3}+\frac{1}{20} \mathrm{NH}_{4}^{+}+\frac{6}{5} \mathrm{H}^{+}+e^{-} \rightarrow \frac{1}{20} \mathrm{C}_{5} \mathrm{H}_{7} \mathrm{O}_{2} \mathrm{~N}_{\mathrm{FeRB}}+\frac{13}{20} \mathrm{H}_{2} \mathrm{O}$

$\mathrm{R}: \mathrm{FeOOH}(\mathrm{s})+0.208 \mathrm{CH}_{4}+0.033 \mathrm{NH}_{4}^{+}+1.925 \mathrm{H}^{+} \rightarrow 0.0417 \mathrm{HCO}_{3}^{-}+1.808 \mathrm{H}_{2} \mathrm{O}+\mathrm{Fe}^{2+}+$ $0.033 \mathrm{C}_{5} \mathrm{H}_{7} \mathrm{O}_{2} \mathrm{~N}_{\mathrm{FeRB}}$

$\underline{\text { AOM coupled to sulfate reduction }}\left(f_{e}=0.92, f_{s}=0.08\right)$

$\mathrm{R}_{\mathrm{d}}: \frac{1}{8} \mathrm{CH}_{4}+\frac{3}{8} \mathrm{H}_{2} \mathrm{O} \rightarrow \frac{1}{8} \mathrm{HCO}_{3}+\frac{9}{8} \mathrm{H}^{+}+e^{-}$

$\mathrm{R}_{\mathrm{a}}: \frac{1}{8} \mathrm{SO}_{4}^{2-}+\frac{9}{8} H^{+}+e^{-} \rightarrow \frac{1}{8} H S^{-}+\frac{1}{2} \mathrm{H}_{2} \mathrm{O}$

$\mathrm{R}_{\mathrm{c}}: \frac{1}{4} \mathrm{HCO}_{3}+\frac{1}{20} \mathrm{NH}_{4}^{+}+\frac{6}{5} \mathrm{H}^{+}+e^{-} \rightarrow \frac{1}{20} \mathrm{C}_{5} \mathrm{H}_{7} \mathrm{O}_{2} \mathrm{~N}_{\mathrm{FeRB}}+\frac{13}{20} \mathrm{H}_{2} \mathrm{O}$

$\mathrm{R}: \quad 0.125 \mathrm{CH}_{4}+0.115 \mathrm{SO}_{4}^{2-}+0.004 \mathrm{NH}_{4}^{+}+0.006 \mathrm{H}^{+} \rightarrow 0.115 \mathrm{HCO}^{-}+0.115 \mathrm{HS}^{-}+$

$0.137 \mathrm{H}_{2} \mathrm{O}+0.004 \mathrm{C}_{5} \mathrm{H}_{7} \mathrm{O}_{2} \mathrm{~N}_{\mathrm{SRB}}$ 
The temporal changes in concentrations of sulfate, hydrogen sulfide, and iron in groundwater from the modeling results are shown in Figure S3. The model was run as a batch system meaning that the reactants are depleted (without replenishment) with time as the solution moves toward equilibrium. For the simulations, the iron-oxide mineral was always present. In contrast to the batch nature of this simple model, the natural system would include groundwater flow that could slowly replenish aqueous reactants. Likewise, if iron oxide was present in the natural system but became depleted, this was not investigated here. The simulation does show eventual depletion in aqueous Fe(II) however as iron sulfide precipitates. The solid sulfide phase that was allowed to precipitate is FeS (am).

The rates of the transient increase and subsequent decrease in iron concentration and the decline rate of sulfate concentration depend on the initial sulfate concentration and not to great extent on goethite concentration. When sulfate is high $(192 \mathrm{mg} / \mathrm{L})$ (considered here to simulate "replenished" groundwater), iron concentration increases above the $0.3 \mathrm{mg} / \mathrm{L}$ threshold defined by Woda et al. (2018) ${ }^{1}$ quickly (within the first 5 days), and subsequently declines below the threshold in $\sim 3$ months. When initial sulfate concentrations are lower, iron concentrations are never observed to drop below the threshold throughout the duration of the model (Figure S3). Likewise, a lower concentration of iron mineral (i.e., goethite) in the simulation leads to a slower rate of increase of aqueous iron concentration. These modeling results document the importance of availability of both the iron mineral and aqueous sulfate in determining the timing and duration of the iron spike and the timing and maintenance of high sulfate concentrations. 


\section{Text S2 Exemplifying the Geochemical Protocol}

In this section, we demonstrate the utility of the protocol in comparison to three putatively contaminated areas across PA (i.e., Gregs Run, Paradise Road, and Chapman State Park) for which geochemical analyses are available. These water chemistry data were compiled from previously published work. ${ }^{10-12}$ As described in the main body of the paper, the data were compared to chosen geochemical criteria including dissolved methane, $\mathrm{Cl}, \mathrm{Na}, \mathrm{Ca}, \mathrm{Fe}$, and $\mathrm{SO}_{4}$. Results are shown in Table S4 and Figure S4. Gregs Run results are shown in the main text and results of the other two sites are discussed below.

The second site is Paradise Road in Bradford County (Figure 1). Llewellyn et al. (2015) ${ }^{10}$ investigated several households impacted by anomalous methane that had apparently migrated from nearby unconventional wells in southeastern Bradford County. These problematic unconventional wells were drilled and hydraulically fractured from mid-2009 to 2010 approximately $2 \mathrm{~km}$ from the impacted household wells. Gas leaking from one or more of these wells may have migrated along joints and faults or stair-cased upward through bedding planes and joints to the valley of the northern branch of Sugar Run along Paradise Road. ${ }^{10}$ Note that this Sugar Run, in Bradford County, differs from the previously discussed Sugar Run in Lycoming County ${ }^{1}$. Using the geochemical protocol on three water samples collected from two impacted water wells reported by Llewellyn et al. ${ }^{10}$, three samples collected on 11/7/2012 (roughly two years after the initial impact) are categorized as type $1(n=2)$ or type $4(n=1)$ (Table S4). It is particularly interesting that one of the three samples was highlighted by the geochemical protocol even two years after the incident began at a location $2 \mathrm{~km}$ from the incident.

The third presumably contaminated site is located around Chapman State Park in Warren County (Figure 1). Bubbling groundwater (methane gas) was first noticed in 02/1983 from local 
domestic water wells, and the investigators believed the methane was due to a nearby gas blowout incident at a conventional well. ${ }^{11,13}$ These groundwater samples were collected from 08/1986 to 07/1987. Based on our testing protocol, three out of six groundwater samples from Chapman State Park are classified as type 5 if we assume censored analyte concentrations (i.e., below detection limit) are at detection limit. The other samples are type 2 because two have slightly higher $\mathrm{Cl}$ concentrations (48 and $33 \mathrm{mg} / \mathrm{L}$ ) than the $\mathrm{Cl}$ threshold of $30 \mathrm{mg} / \mathrm{L}$ and one has slightly lower $\mathrm{Ca} / \mathrm{Na}$ ratio (0.51) compared to the threshold value of 0.52 . Regardless of brine signatures in these water samples, all of these groundwaters show levels of sulfate and/or Fe above the thresholds of 6 and $0.3 \mathrm{mg} / \mathrm{L}$, respectively. 


\section{References}

(1) Woda, J.; Wen, T.; Oakley, D.; Yoxtheimer, D.; Engelder, T.; Castro, M. C.; Brantley, S. L. Detecting and Explaining Why Aquifers Occasionally Become Degraded near Hydraulically Fractured Shale Gas Wells. Proc. Natl. Acad. Sci. 2018, 115 (49), 1234912358.

(2) Beal, E. J.; House, C. H.; Orphan, V. J. Manganese- and Iron-Dependent Marine Methane Oxidation. Science (80-. ). 2009, 325 (5937), 184-187.

(3) Ettwig, K. F.; Zhu, B.; Speth, D.; Keltjens, J. T.; Jetten, M. S. M.; Kartal, B. Archaea Catalyze Iron-Dependent Anaerobic Oxidation of Methane. Proc. Natl. Acad. Sci. 2016, 113 (45), 12792-12796.

(4) Steefel, C. I.; DePaolo, D. J.; Lichtner, P. C. Reactive Transport Modeling: An Essential Tool and a New Research Approach for the Earth Sciences. Earth Planet. Sci. Lett. 2005, 240 (3-4), 539-558.

(5) Wendt, A. K.; Sowers, T.; Hynek, S.; Lemon, J.; Beddings, E.; Zheng, G.; Li, Z.; Williams, J. Z.; Brantley, S. L. Scientist-Nonscientist Teams Explore Methane Sources in Streams Near Oil/Gas Development. J. Contemp. Water Res. Educ. 2018, 164 (1), 80-111.

(6) Rittmann, B. E.; VanBriesen, J. M. Microbiological Processes in Reactive Modeling. Rev. Miner. 1996, 34, 311-334.

(7) Li, L.; Steefel, C. I.; Kowalsky, M. B.; Englert, A.; Hubbard, S. S. Effects of Physical and Geochemical Heterogeneities on Mineral Transformation and Biomass Accumulation during Biostimulation Experiments at Rifle, Colorado. J. Contam. Hydrol. 2010, 112 (14), 45-63.

(8) Christensen, T. H.; Bjerg, P. L.; Banwart, S. a; Jakobsen, R.; Heron, G.; Albrechtsen, H.-J. Characterization of Redox Conditions in Pollution Plumes. J. Contam. Hydrol. 2000, 45, 165-241.

(9) Bethke, C. M.; Sanford, R. A.; Kirk, M. F.; Jin, Q.; Flynn, T. M. The Thermodynamic Ladder in Geomicrobiology. Am. J. Sci. 2011, 311 (3), 183-210.

(10) Llewellyn, G. T.; Dorman, F.; Westland, J. L.; Yoxtheimer, D.; Grieve, P.; Sowers, T.; Humston-Fulmer, E.; Brantley, S. L. Evaluating a Groundwater Supply Contamination Incident Attributed to Marcellus Shale Gas Development. Proc. Natl. Acad. Sci. 2015, 112 (20), 6325-6330.

(11) Moore, M. E.; Buckwalter, T. F. Ground-Water Resources Data for Warren County, Pennsylvania; 1996.

(12) Pennsylvania Department of Environmental Protection. PA DEP eMAP http://www.depgis.state.pa.us/emappa/ (accessed Jan 1, 2018).

(13) Walker, J. T. Subsurface Gas Blowouts in Pennsylvania and Elsewhere; 1984.

(14) Pennsylvania Department of Environmental Protection. Pennsylvania Digitized Mined Areas http://www.pasda.psu.edu/uci/DataSummary.aspx?dataset=257 (accessed Jul 13, 2018).

(15) Pennsylvania Department of Environmental Protection. PA Oil and Gas Mapping http://www.depgis.state.pa.us/PaOilAndGasMapping (accessed Jan 1, 2018). 


\section{SI Figures}

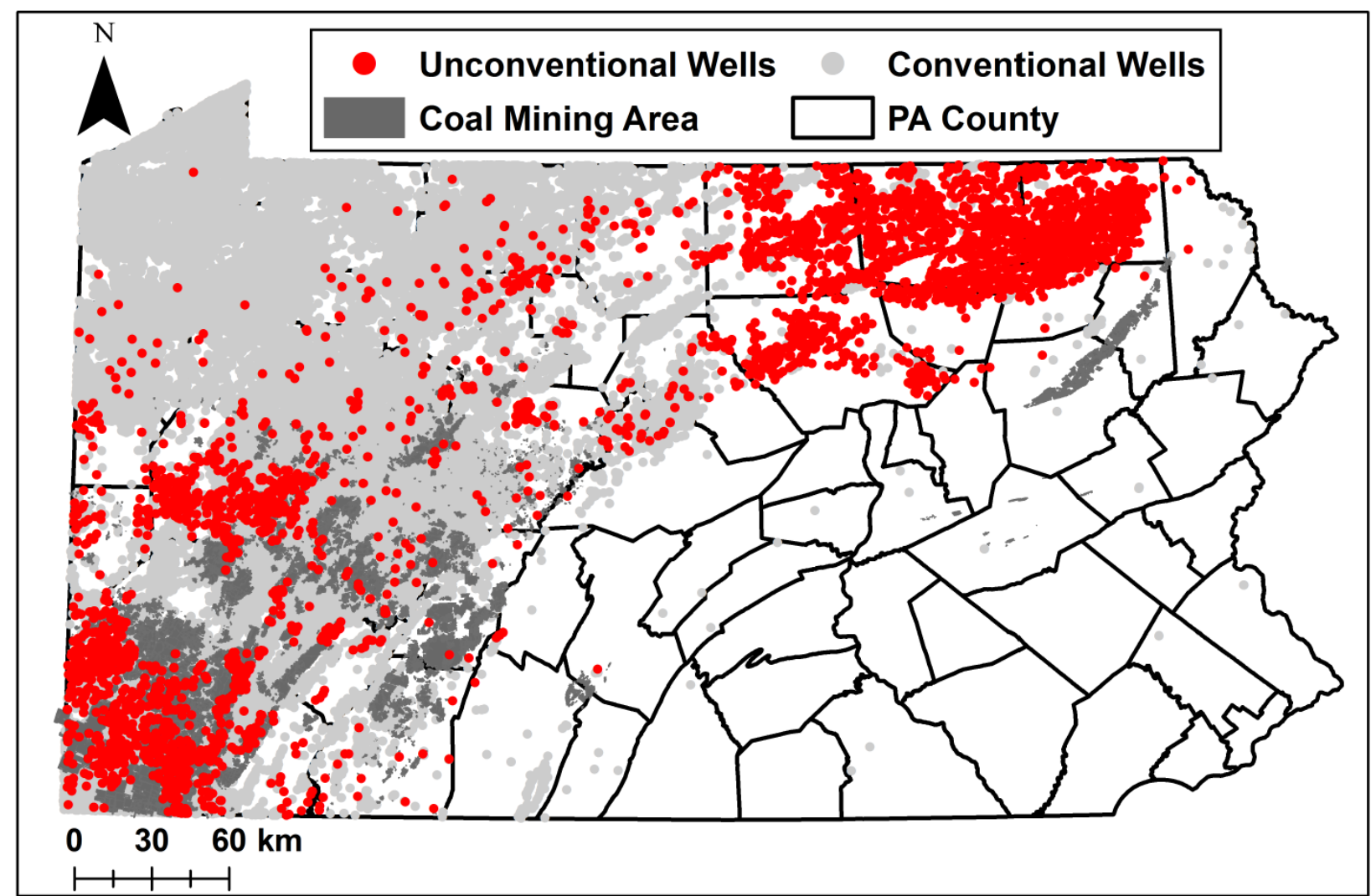

Figure S1. Location maps of conventional wells (light grey), unconventional wells (red), and coal mining areas (dark grey) in PA. These map layers were downloaded from PA DEP websites in January $2018 .{ }^{14,15}$ 


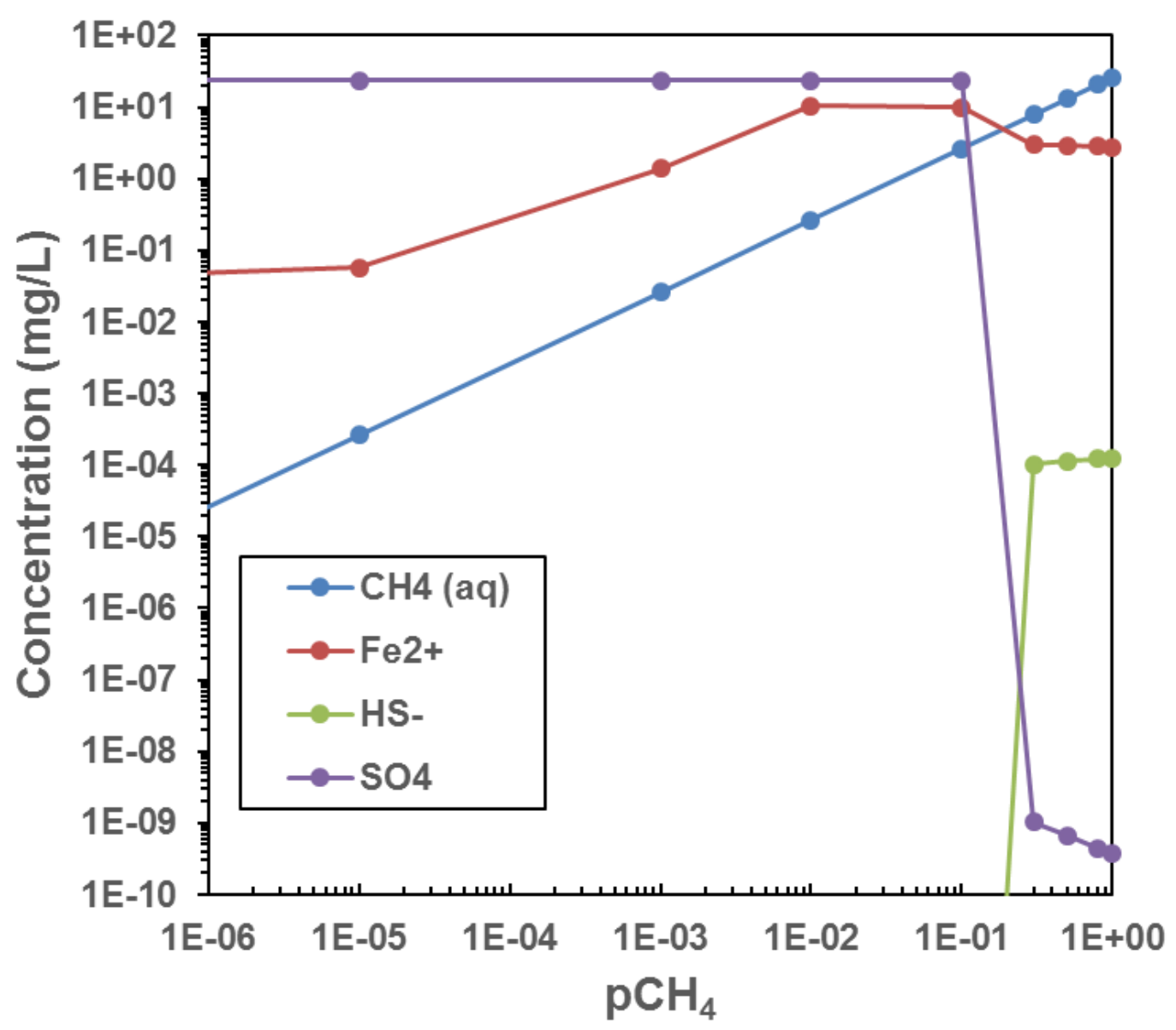

Figure S2. Modeling results of groundwater geochemistry (aqueous $\mathrm{CH}_{4}, \mathrm{Fe}^{2+}, \mathrm{HS}^{-}$, and $\mathrm{SO}_{4}{ }^{2}$ ) as a function of partial pressure of methane ranging from $1 \times 10^{-6}$ to 1 atm as calculated with Geochemist's Workbench version 9.0. Waters were set to mimic groundwater samples with elevated methane, sulfate, and iron in test dataset as described in text. Goethite was present in the system initially at $10 \mathrm{wt} \%$ but above about $8 \mathrm{mg} / \mathrm{L}$ of $\mathrm{CH}_{4}$, goethite has transformed to iron sulfide (pyrite). 

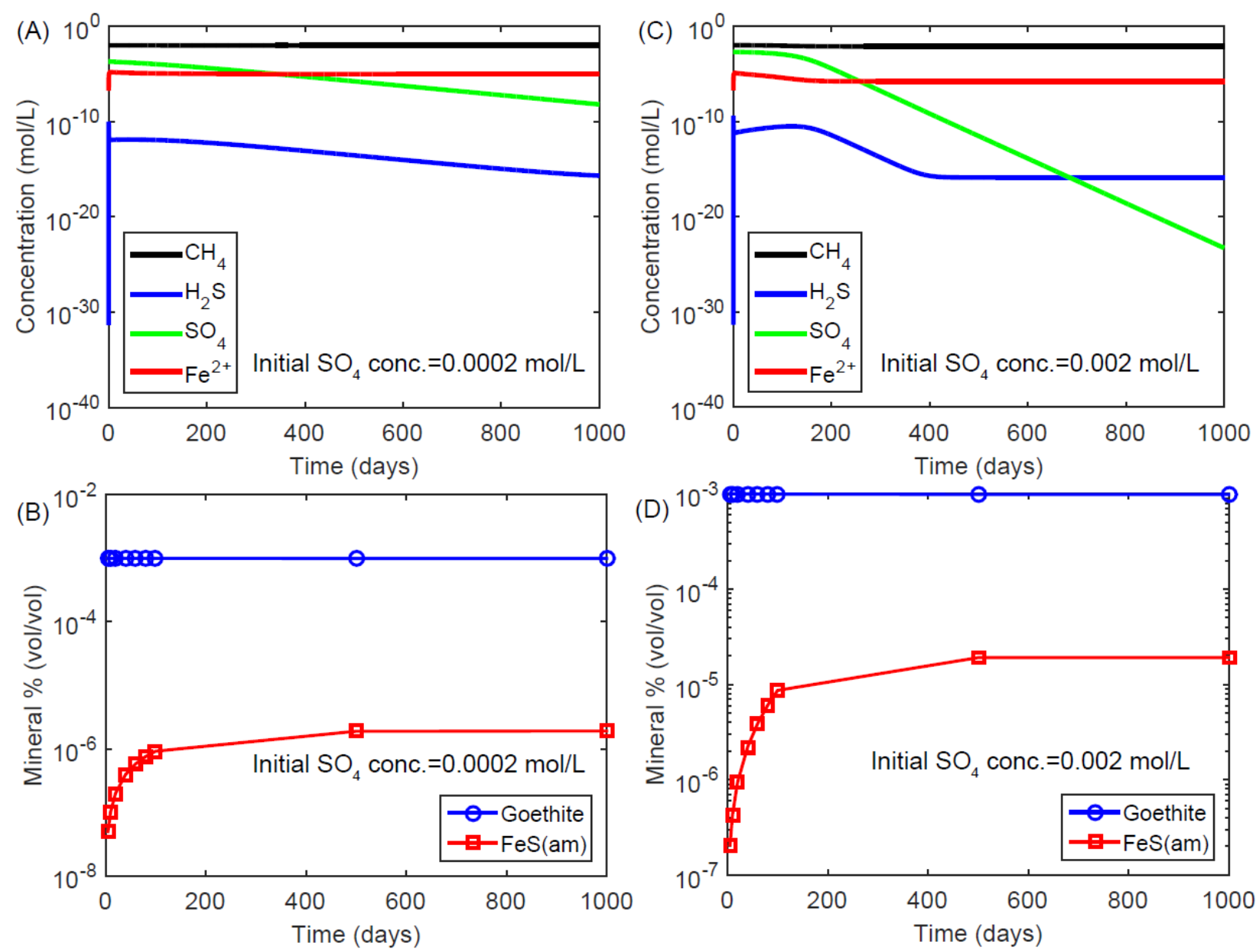

Figure S3. Temporal change (0-1000 days) of concentrations of sulfate, sulfide and aqueous iron in groundwater derived from the results of CrunchFlow batch model. The invasion of anomalous methane starts at day 0 . Initial $\mathrm{H}_{2} \mathrm{~S}$ concentration was set to $1 \times 10^{-40} \mathrm{~mol} / \mathrm{L}$. Goethite was set to $0.001 \%(\mathrm{vol} / \mathrm{vol})$. 

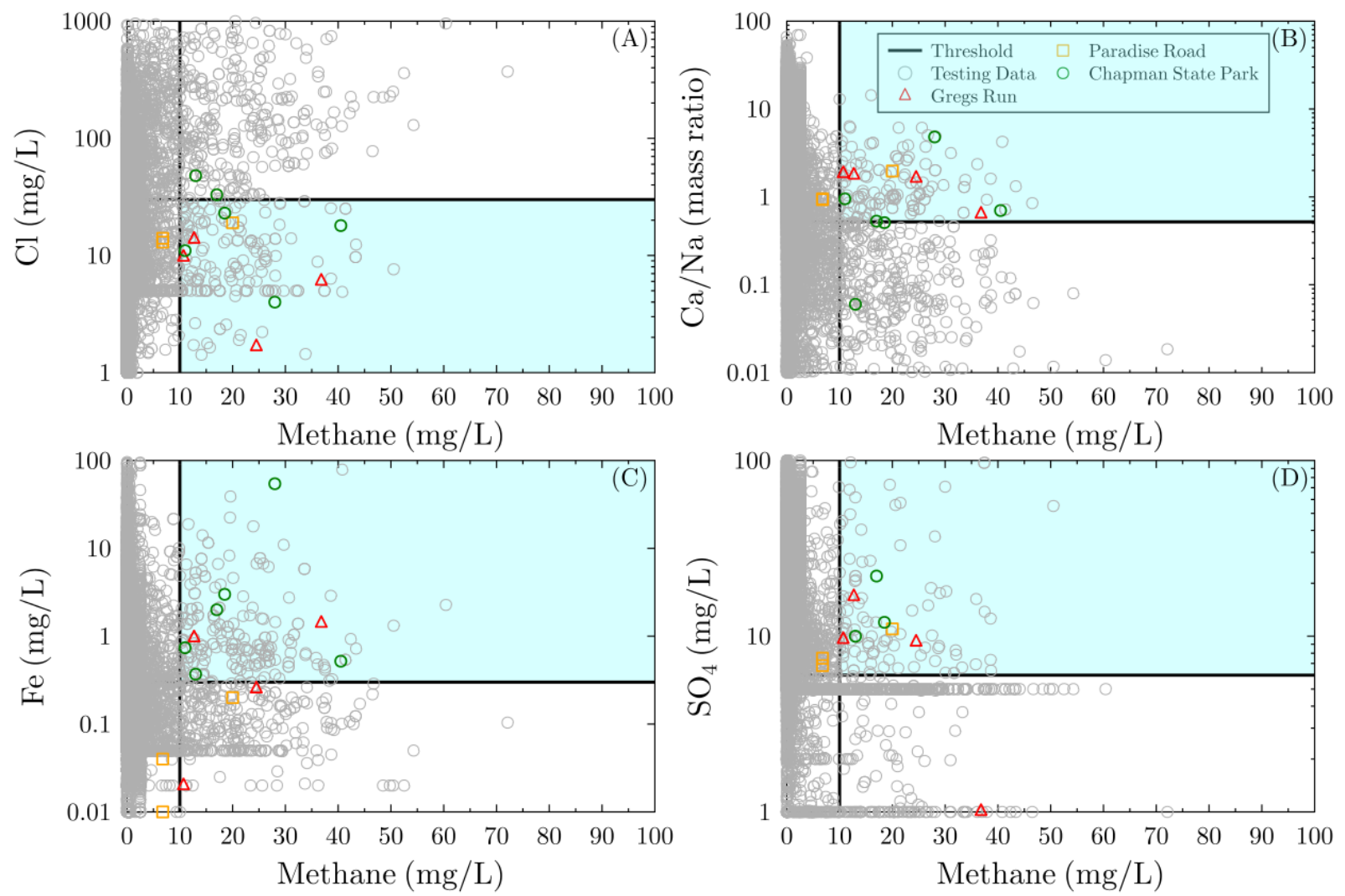

Figure S4. (A) Cl concentration, (B) Ca/Na concentration (mg/L) ratio, (C) Fe concentration, and (D) sulfate concentration plotted versus methane concentration in groundwater samples from test dataset (grey symbols) and from putatively impacted areas in PA. Symbols refer to Gregs Run (red triangle), Paradise Road (orange square), and Chapman State Park (green circle). Solid black lines represent the boundary between water samples that warrant (blue quadrant) or do not warrant further investigation for anomalous (new) methane as defined in main text. 


\section{SI Tables}

Table S1a. Water chemistry input to geochemical modeling (GWB v. 9). Methane fugacity was varied from $1 \times 10^{-6}$ up to 1 atm

\begin{tabular}{ccc}
\hline Analyte & Unit & Model Input $^{1}$ \\
\hline $\mathrm{HCO}_{3}{ }^{-}$ & $\mathrm{mg} / \mathrm{L}$ & 4.7 \\
$\mathrm{Ca}^{2+}$ & $\mathrm{mg} / \mathrm{L}$ & 62 \\
${ }^{2} \mathrm{Cl}^{-}$ & $\mathrm{mg} / \mathrm{L}$ & 106 \\
$\mathrm{Fe}^{2+}$ & $\mathrm{mg} / \mathrm{L}$ & 0 \\
$\mathrm{Mg}^{2+}$ & $\mathrm{mg} / \mathrm{L}$ & 12 \\
$\mathrm{Mn}^{2+}$ & $\mathrm{mg} / \mathrm{L}$ & 0.22 \\
$\mathrm{~K}^{+}$ & $\mathrm{mg} / \mathrm{L}$ & 2.0 \\
$\mathrm{Na}^{+}$ & $\mathrm{mg} / \mathrm{L}$ & 274 \\
$\mathrm{SO}_{4}{ }^{2-}$ & $\mathrm{mg} / \mathrm{L}$ & $1 \times 10^{-10}$ or 28 \\
$\mathrm{pH}^{2}$ & $\mathrm{pH}$ unit & 8.0 \\
$\mathrm{O}_{2}$ (aq) & $\mathrm{mg} / \mathrm{L}$ & $1.00 \mathrm{E}-10$ \\
Temperature & ${ }^{\circ} \mathrm{C}$ & 25 \\
$\mathrm{TDS}$ & $\mathrm{mg} / \mathrm{L}$ & 945
\end{tabular}

${ }^{1}$ listed values were averaged from groundwater data included in the large dataset reported in this study that contain high methane $(>10 \mathrm{mg} / \mathrm{L})$ and elevated sulfate $(>6 \mathrm{mg} / \mathrm{L})$ and iron $(>0.3 \mathrm{mg} / \mathrm{L})$ ${ }^{2}$ charge balance on $\mathrm{Cl}$

Table S1b. Initial aqueous species in CrunchFlow batch model (Temperature $=25^{\circ} \mathrm{C}$; Goethite: $0.001 \%$ vol/vol; Secondary species: $\mathrm{OH}^{-}, \mathrm{CO}_{3}{ }^{2-}, \mathrm{HCO}_{3}{ }^{-}, \mathrm{S}^{2-}, \mathrm{HS}^{-}, \mathrm{NH}_{4}{ }^{+}$)

\begin{tabular}{cc}
\hline Aqueous Species & Concentration $(\mathrm{mol} / \mathrm{L})$ \\
\hline${ }^{1} \mathrm{Fe}^{2+}$ & $1.8 \mathrm{E}-7$ \\
$\mathrm{Fe}^{3+}$ & $2.7 \mathrm{E}-26$ \\
$\mathrm{Mn}^{2+}$ & $1.0 \mathrm{E}-7$ \\
${ }^{1} \mathrm{Ca}^{2+}$ & $3.5 \mathrm{E}-04$ \\
${ }^{1} \mathrm{Na}^{+}$ & $1.5 \mathrm{E}-03$ \\
$\mathrm{SiO}_{2}$ & $1.7 \mathrm{E}-6$ \\
$\mathrm{~S}^{2}$ & $2.9 \mathrm{E}-16$ \\
$\mathrm{H}_{2} \mathrm{~S}$ & $1 \mathrm{E}-40$ \\
$\mathrm{SO}_{4}{ }^{2-}$ & $2.0 \mathrm{E}-03$ or $2.0 \mathrm{E}-4$ \\
${ }^{1} \mathrm{Cl}^{-}$ & $2.2 \mathrm{E}-04$ \\
${ }^{1} \mathrm{CO}_{2}$ & $8.1 \mathrm{E}-6$ \\
$\mathrm{O}_{2}$ & $2.0 \mathrm{E}-10$ \\
$\mathrm{SRB}$ and FeRB & $1 \mathrm{E}-20$ \\
$\mathrm{NH}_{3}$ & $1.0 \mathrm{E}-2$ \\
${ }^{1} \mathrm{pH}^{2}$ & 8.7 \\
${ }^{1}$ measured in $\mathrm{HO}$ groundwater & \\
${ }^{2}$ sulfate and iron reducing bacteria &
\end{tabular}


Table S2. Summary of validation and test data discussed in this study

\begin{tabular}{|c|c|c|c|c|c|}
\hline Dataset & Counties & Data Source & $\begin{array}{c}\text { Sampling } \\
\text { Year }\end{array}$ & $\begin{array}{c}\text { \# of Groundwater } \\
\text { Sample } \\
\end{array}$ & $\begin{array}{c}\text { \# of Complete } \\
\text { Record } \\
\end{array}$ \\
\hline Gregs Run & Southeastern Lycoming & PA DEP eMAP & 2016 & 5 & 5 \\
\hline Paradise Road & Southeastern Bradford & $\begin{array}{l}\text { Llewellyn et al. } \\
\qquad(2015)\end{array}$ & 2012 & 3 & 3 \\
\hline $\begin{array}{l}\text { Chapman State } \\
\text { Park }\end{array}$ & Central Warren & $\begin{array}{c}\text { Moore and } \\
\text { Buckwalter (1996) }\end{array}$ & 1986-1987 & 6 & 6 \\
\hline $\begin{array}{l}\text { Northeastern PA } \\
\text { (NE PA) }\end{array}$ & $\begin{array}{l}\text { Bradford, Susquehanna, Wyoming, } \\
\text { Sullivan, Tioga, Potter }\end{array}$ & PA DEP pre-drill & $2008-2016$ & 16,692 & 15,510 \\
\hline $\begin{array}{l}\text { Northwestern PA } \\
\text { (NW PA) }\end{array}$ & $\begin{array}{l}\text { Erie, Crawford, Mercer, Lawrence, Butler, } \\
\text { Venango, Warren, Clarion, Jefferson }\end{array}$ & PA DEP pre-drill & $\begin{array}{l}\text { 1958-1999; } \\
\text { 2012-2015 }\end{array}$ & 3,446 & 2,739 \\
\hline $\begin{array}{l}\text { Southwestern PA } \\
\text { (SW PA) }\end{array}$ & Beaver, Washington, Greene & PA DEP pre-drill & 2010-2016 & 2,514 & 2,502 \\
\hline
\end{tabular}


Table S3. County area, groundwater samples, and summary of conventional and unconventional wells, and coal mining for each of these eighteen counties covered in this study

\begin{tabular}{|c|c|c|c|c|c|c|c|c|}
\hline $\begin{array}{l}\text { County } \\
\text { Name }\end{array}$ & $\begin{array}{c}\text { County } \\
\text { Area } \\
\left(\mathbf{k m}^{2}\right)\end{array}$ & $\begin{array}{c}\text { \# of } \\
\text { Groundwater } \\
\text { Sample }\end{array}$ & $\begin{array}{c}\text { \# of } \\
\text { Complete } \\
\text { Record }\end{array}$ & $\begin{array}{c}\text { \# of } \\
\text { Unconventional } \\
\text { Wells }\end{array}$ & $\begin{array}{c}\# \text { of } \\
\text { Conventional } \\
\text { Wells }\end{array}$ & $\begin{array}{l}\text { Unconventional } \\
\text { Well Density } \\
\left(\text { per } \mathbf{k m}^{2}\right)\end{array}$ & $\begin{array}{l}\text { Conventional } \\
\text { Well Density } \\
(\text { per km²) }\end{array}$ & $\begin{array}{c}\text { Percentage } \\
\text { of Area for } \\
\text { Coal } \\
\text { Mining } \\
\end{array}$ \\
\hline NE PA & 13134 & 16692 & 15510 & 4219 & 2236 & 0.32 & 0.17 & $0.01 \%$ \\
\hline Bradford & 3008 & 11296 & 11218 & 1385 & 66 & 0.46 & 0.02 & $<0.01 \%$ \\
\hline Susquehanna & 2156 & 1948 & 849 & 1384 & 9 & 0.64 & $<0.01$ & $0.06 \%$ \\
\hline Sullivan & 1171 & 1889 & 1886 & 137 & 3 & 0.12 & $<0.01$ & $<0.01 \%$ \\
\hline Wyoming & 1050 & 1418 & 1416 & 269 & 11 & 0.26 & 0.01 & $<0.01 \%$ \\
\hline Tioga & 2946 & 118 & 118 & 947 & 283 & 0.32 & 0.10 & $<0.01 \%$ \\
\hline Potter & 2803 & 23 & 23 & 97 & 1864 & 0.03 & 0.66 & $<0.01 \%$ \\
\hline$N W P A$ & 16905 & 3446 & 2739 & 765 & 50808 & 0.05 & 3.01 & $1.01 \%$ \\
\hline Mercer & 1767 & 2476 & 2013 & 61 & 3651 & 0.03 & 2.07 & $0.01 \%$ \\
\hline Lawrence & 940 & 295 & 278 & 71 & 237 & 0.08 & 0.25 & $<0.01 \%$ \\
\hline Warren & 2328 & 220 & 150 & 3 & 14781 & $<0.01$ & 6.35 & $<0.01 \%$ \\
\hline Venango & 1770 & 143 & 96 & 6 & 11215 & $<0.01$ & 6.34 & $<0.01 \%$ \\
\hline Jefferson & 1696 & 109 & 58 & 58 & 6215 & 0.03 & 3.66 & $7.26 \%$ \\
\hline Crawford & 2688 & 94 & 76 & 3 & 4049 & $<0.01$ & 1.51 & $<0.01 \%$ \\
\hline Clarion & 1574 & 77 & 36 & 37 & 4501 & 0.02 & 2.86 & $0.90 \%$ \\
\hline Butler & 2060 & 24 & 24 & 525 & 2320 & 0.25 & 1.13 & $1.63 \%$ \\
\hline Erie & 2081 & 8 & 8 & 1 & 3839 & $<0.01$ & 1.84 & $0.00 \%$ \\
\hline$S W P A$ & 4882 & 2514 & 2502 & 2816 & 7891 & 0.58 & 1.62 & $35.12 \%$ \\
\hline Washington & 2233 & 1730 & 1719 & 1588 & 3430 & 0.71 & 1.54 & $43.86 \%$ \\
\hline Beaver & 1151 & 415 & 414 & 72 & 266 & 0.06 & 0.23 & $0.78 \%$ \\
\hline Greene & 1498 & 369 & 369 & 1156 & 4195 & 0.77 & 2.80 & $48.48 \%$ \\
\hline
\end{tabular}


Table S4. Compiled groundwater quality data collected from three sites in PA putatively contaminated by anomalous methane

\begin{tabular}{|c|c|c|c|c|c|c|c|c|c|c|c|c|}
\hline Sampling Site & $\begin{array}{l}\text { Sampling } \\
\text { Date }\end{array}$ & Data Source & Latitude & Longitude & $\begin{array}{c}\mathrm{CH}_{4} \\
(\mathrm{mg} / \mathrm{L})\end{array}$ & $\begin{array}{c}\mathrm{Cl} \\
(\mathrm{mg} / \mathrm{L})\end{array}$ & $\begin{array}{c}\mathrm{Ca} \\
(\mathrm{mg} / \mathrm{L})\end{array}$ & $\begin{array}{c}\mathrm{Na} \\
(\mathrm{mg} / \mathrm{L})\end{array}$ & $\mathrm{Ca} / \mathrm{Na}$ & $\begin{array}{l}\text { Sulfate } \\
(\mathrm{mg} / \mathrm{L})\end{array}$ & $\begin{array}{c}\mathrm{Fe} \\
(\mathrm{mg} / \mathrm{L})\end{array}$ & $\begin{array}{l}\text { Water } \\
\text { Type }\end{array}$ \\
\hline \multicolumn{13}{|c|}{ Gregs Run, Lycoming County, PA } \\
\hline GR 1 & $6 / 14 / 2016$ & PA DEP eMap & - & - & 24.5 & 1.67 & 14.07 & 8.586 & 1.64 & 9.28 & 0.253 & Type 4 \\
\hline GR 1 & $6 / 4 / 2018$ & this study & - & - & 24 & 1.3 & 10.4 & 5.96 & 1.74 & 6.1 & 0.39 & Type 5 \\
\hline GR 2 & $6 / 20 / 2016$ & PA DEP eMap & - & - & 10.7 & 9.71 & 15.8 & 8.536 & 1.85 & 9.61 & $<0.02$ & Type 4 \\
\hline GR 3 & $6 / 14 / 2016$ & PA DEP eMap & - & - & 36.8 & 6.06 & 12.9 & 20.2 & 0.64 & 1.01 & 1.41 & Type 3 \\
\hline GR 4 & $6 / 14 / 2016$ & PA DEP eMap & - & - & 12.7 & 13.8 & 20.6 & 11.6 & 1.78 & 16.84 & 0.965 & Type 5 \\
\hline \multicolumn{13}{|c|}{ Paradise Road, Bradford County, PA } \\
\hline PLG-12-65 & $11 / 7 / 2012$ & \multirow{3}{*}{$\begin{array}{l}\text { Llewellyn et al. } \\
\text { (2015) }\end{array}$} & 41.641 & -76.294 & 20 & 19 & 36.7 & 18.6 & 1.97 & 11 & 0.2 & Type 4 \\
\hline PLG-12-69 post-purge & $11 / 7 / 2012$ & & 41.643 & -76.294 & 6.76 & 13 & 28.1 & 30.1 & 0.93 & 7.5 & 0.01 & Type 1 \\
\hline PLG-12-69 pre-purge & $11 / 7 / 2012$ & & 41.643 & -76.294 & 6.76 & 14 & 28.8 & 30.3 & 0.95 & 6.8 & 0.04 & Type 1 \\
\hline \multicolumn{13}{|c|}{ Chapman State Park, Warren County, PA } \\
\hline 564 & $8 / 14 / 1986$ & \multirow{6}{*}{$\begin{array}{c}\text { Moore and } \\
\text { Buckwalter } \\
\text { (1996) }\end{array}$} & 41.751 & -79.169 & 13 & 48 & 5.1 & 80 & 0.06 & 10 & 0.37 & Type 2 \\
\hline 569 & $8 / 21 / 1986$ & & 41.757 & -79.171 & 17 & 33 & 33 & 62 & 0.53 & 22 & 2 & Type 2 \\
\hline 571 & $8 / 28 / 1986$ & & 41.762 & -79.170 & 28 & 4 & 26 & 5.4 & 4.81 & $<10$ & 54.4 & Type 5 \\
\hline 572 & $8 / 28 / 1986$ & & 41.761 & -79.174 & 40.5 & 18 & 26 & 37 & 0.70 & $<10$ & 0.52 & Type 5 \\
\hline 578 & $6 / 17 / 1987$ & & 41.746 & -79.178 & 18.5 & 23 & 26 & 51 & 0.51 & 12 & 3 & Type 2 \\
\hline 579 & $7 / 30 / 1987$ & & 41.745 & -79.179 & 11 & 11 & 21 & 22 & 0.95 & $<10$ & 0.74 & Type 5 \\
\hline
\end{tabular}


Table S5. List of groundwater samples in test dataset that are categorized as type 4 and type 5

\begin{tabular}{|c|c|c|c|c|c|c|c|c|c|c|c|c|c|}
\hline $\begin{array}{c}\text { Sample } \\
\text { ID }\end{array}$ & $\begin{array}{c}\text { Site } \\
\text { ID }\end{array}$ & Region & $\begin{array}{c}\text { Sampling } \\
\text { Date }\end{array}$ & Latitude & Longitude & $\begin{array}{c}\mathrm{CH}_{4} \\
(\mathrm{mg} / \mathrm{L})\end{array}$ & $\begin{array}{c}\mathrm{Cl} \\
(\mathrm{mg} / \mathrm{L})\end{array}$ & $\begin{array}{c}\mathrm{Ca} \\
(\mathrm{mg} / \mathrm{L})\end{array}$ & $\begin{array}{c}\mathrm{Na} \\
(\mathrm{mg} / \mathrm{L})\end{array}$ & $\mathrm{Ca} / \mathrm{Na}$ & $\begin{array}{c}\mathrm{SO}_{4} \\
(\mathrm{mg} / \mathrm{L})\end{array}$ & $\begin{array}{c}\text { Fe } \\
(\mathrm{mg} / \mathrm{L})\end{array}$ & $\begin{array}{c}\text { Water } \\
\text { Type }\end{array}$ \\
\hline 1 & 1 & NEPA & $1 / 20 / 2011$ & 41.667 & -76.795 & 10.3 & $<5$ & 55.1 & 27.5 & 2.00 & 9.5 & 0.56 & Type 5 \\
\hline 2 & 1 & NEPA & $12 / 30 / 2011$ & 41.686 & -76.758 & 15.7 & 1.6 & 41.8 & 64.0 & 0.65 & 6.3 & $<0.05$ & Type 4 \\
\hline 3 & 1 & NEPA & $12 / 2 / 2010$ & 41.665 & -76.796 & 10.5 & $<5$ & 41.3 & 16.5 & 2.50 & 6.8 & 0.10 & Type 4 \\
\hline 4 & 2 & NEPA & $4 / 18 / 2011$ & 41.757 & -76.663 & 12.1 & $<5$ & 111.0 & 51.7 & 2.15 & 97.6 & 1.53 & Type 5 \\
\hline 5 & 2 & NEPA & $6 / 23 / 2011$ & 41.726 & -76.656 & 15.8 & 8.0 & 35.6 & 42.2 & 0.84 & 6.0 & 0.21 & Type 4 \\
\hline 6 & 3 & NEPA & $12 / 13 / 2011$ & 41.729 & -76.551 & 14.1 & 1.4 & 94.4 & 38.6 & 2.45 & 40.4 & 0.22 & Type 4 \\
\hline 7 & 3 & NEPA & $10 / 3 / 2011$ & 41.722 & -76.563 & 20.6 & 7.9 & 55.8 & 55.8 & 1.00 & 55.8 & 0.10 & Type 4 \\
\hline 8 & 4 & NEPA & $11 / 12 / 2012$ & 41.819 & -76.743 & 15.8 & 24.7 & 62.6 & 15.6 & 4.01 & 26.9 & 0.15 & Type 4 \\
\hline 9 & 5 & NEPA & $3 / 9 / 2011$ & 41.857 & -76.423 & 10.1 & $<5$ & 40.9 & 23.7 & 1.73 & 13.8 & 0.33 & Type 5 \\
\hline 10 & 6 & NEPA & $1 / 17 / 2012$ & 41.707 & -76.336 & 15.2 & 1.8 & 29.9 & 13.4 & 2.23 & 12.1 & $<0.05$ & Type 4 \\
\hline 11 & 7 & NEPA & $12 / 13 / 2010$ & 41.854 & -76.320 & 27.5 & $<5$ & 39.0 & 29.8 & 1.31 & 10.1 & 0.99 & Type 5 \\
\hline 12 & 7 & NEPA & $12 / 13 / 2010$ & 41.854 & -76.320 & 38.6 & 6.3 & 36.7 & 22.8 & 1.61 & 7.3 & 2.89 & Type 5 \\
\hline 13 & 8 & NEPA & $11 / 4 / 2010$ & 41.770 & -76.053 & 10.3 & $<5$ & 24.5 & 6.4 & 3.82 & 16.1 & 0.84 & Type 5 \\
\hline 14 & 9 & NWPA & $1 / 18 / 1995$ & 41.250 & -80.397 & 12.0 & 6.4 & 52.3 & 8.5 & 6.12 & 49.4 & 2.04 & Type 5 \\
\hline 15 & 10 & NWPA & $1 / 16 / 1995$ & 41.235 & -80.137 & 10.5 & 26.0 & 51.0 & 29.0 & 1.76 & 45.3 & 0.16 & Type 4 \\
\hline 16 & 11 & NWPA & 2/17/1999 & 41.107 & -80.404 & 11.9 & 14.0 & 64.9 & 10.2 & 6.38 & 68.3 & $<0.04$ & Type 4 \\
\hline 17 & 12 & NWPA & 9/17/1996 & 41.116 & -80.249 & 10.0 & 5.4 & 31.7 & 2.5 & 12.94 & 23.0 & 0.01 & Type 4 \\
\hline
\end{tabular}

